\title{
Evaluation of the Efficacy of Phytochemical Treatment of Surface Waters Based on Powder Extracts of Almond Seeds Moringa Oleifera Lam in kenge, DRC
}

\author{
Cush Ngonzo Luwesi*1, Frédérick Mulwele Ndombe ${ }^{2}$, Dieudoné Musibono Eyulanki ${ }^{3}$, Théophile \\ Mbemba Fundu ${ }^{4}$, Ruffin Kikakedimau Nakweti ${ }^{5}$ and Rigobert Lunga Zola ${ }^{6}$ \\ ${ }^{1}$ Associate Professor, Faculty of Economics, DRC \\ ${ }^{2} \mathrm{PhD}$ student, Department of Biology, Faculty of Sciences, DRC
}

${ }^{3}$ Ordinary Professor, Department of Environmental Sciences, Faculty of Sciences, DRC

${ }^{4}$ Ordinary Professor, Department of Biology, Faculty of Sciences, DRC

${ }^{5}$ Associate Professor, Department of Biology, Exact Sciences Section, DRC

${ }^{6}$ Assistant, Kwango University, Faculty of Agricultural Sciences, DRC

*Corresponding author: Cush Ngonzo Luwesi, Associate Professor, Kwango University, Faculty of Economics, Kenge, DRC

\section{ARTICLE INFO}

Received: 豐 May 06, 2019

Published: May 16, 2019

Citation: Cush Ngonzo L, Frédérick Mulwele N, Dieudoné Musibono E, Théophile Mbemba F, Ruffin Kikakedimau N, Rigobert Lunga Z. Evaluation of the Efficacy of Phytochemical Treatment of Surface Waters Based on Powder Extracts of Almond Seeds Moringa Oleifera Lam in kenge, DRC. Biomed J Sci \& Tech Res 18(1)-2019. BJSTR. MS.ID.003101.

Keywords: Bacterial Activity; Moringa Oleifera Lam; Phytochemical Treatment; Surface Water; Water-Borne Disease

Abbreviations: CMI: Minimal Inhibitory Concentration; BMPs: Best Management Practices; MICs: Minimum Inhibitory Concentrations; CDOM: Colored Dissolved Organic Matter; TSN: Neomycin Trypcase Sulfite

\section{ABSTRACT}

Rural and Periurban Populations in the Democratic Republic of Congo (DRC). Therefore, many people are supposed to be drinking, even though no chemical testing has been undertaken to testify it. This is the cause of several water borne diseases and children. This study sampled six sources of water in the city of Kenge. These samples were treated with the help of Moringa Oleifera Lam seeds to check the effectiveness and evaluate the antibacterial activity of this phytochemical treatment. Physicochemical qualities of this water were retrieved from a multi-parameter analyzer 340i. The bacterial enumeration was carried out by the technique of incorporation of water in a solid medium. Amounts of almond of M. Oleifera Lam seed have been used in this treatment. It is clear that M. Oleifera Lam reaches areas of inhibition of about 21, 16 and $10 \mathrm{~mm}$ for the bacterial activity of Staphylococcus aureus, Salmonella typhi and Escherichia coli, respectively. These results consolidate the fact that M. Oleifera Lam is a pharmacy-tree and a tree of life that can prevent water-borne diseases when added to water.

\section{Summary}

In rural and peri-urban areas of the Democratic Republic of Congo (DRC), populations are particularly confronted with serious problems of drinking water supply. As a result, people rely on drinking water sources that no chemical test has proven. The latter is at the root of several deadly water diseases in both children and adults. In this study, the surface waters of the City of Kenge were treated with almond seed powder from Moringa Oleifera Lam to test its effectiveness and evaluate its antibacterial activity. The physicochemical qualities of these waters were determined using a $340 \mathrm{i}$ multi-parameter analyzer. Bacterial enumeration was performed by the technique of incorporating water into a solid medium. Almond seed doses of M. Oleifera Lam were used as physical means to evaluate efficacy. The results obtained show that a zone of inhibition of bacterial activity of the order of $21 \mathrm{~mm}$ for Staphylococcus aureus, $16 \mathrm{~mm}$ for Salmonella typhi and $10 \mathrm{~mm}$ for Escherichia coli, on average. This confirms the virtues of the antibacterial activity of Mr. Oleifera Lam, which is also nicknamed "plant-pharmacy" or "tree of life", when this plant is added to water.

\section{Introduction}

"Water is life," it is said, but the quality of water is just as essential as that of food consumed by the population to ensure their good health and achieve good socio-economic returns. Several studies highlight the quality of water as one of the vectors of parasitic, 
bacterial and viral diseases of poisoning and sanitary disorders, especially since it can carry all kinds of inert and living substances, some may be harmful to the human body [1,2] (WHO 2006). Thus, if the water resources are poorly managed, the lack of drinkability or the toxicity of the water can lead to a degradation of the human health and to the decrease of the yields of the populations, and this because of the infections induced by the consumption contaminated drinking water. These problems are at the root of the vulnerability of development due to waterborne diseases in some areas of the world (Figure 1). As a result, people rely on drinking water sources to satisfy their daily needs, without any chemical test attesting to the drinkability of these waters.

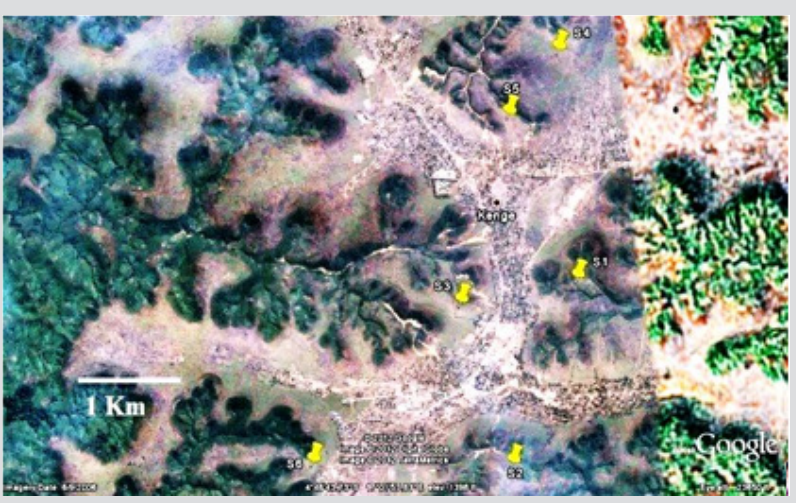

Figure 1: Cartographie des collines et vallées de la Ville de Kenge (Google, 2018).

This practice is at the root of many deadly waterborne diseases in both children and adults. Hence the need for a study to both evaluate the potability of water and the effectiveness of an ingenious or biochemical treatment that would be within reach of poor Kenge households in order to improve the quality of water. drinking water supply in rural and peri-urban areas. This study aims specifically to evaluate the physicochemical and microbiological (bacteriological) quality of water sources. This will be mainly to determine the effective dose of drinking water treatment based on almond powder extracts from the seeds of Moringa Oleifera Lam. Subsequently, a chemical screening will measure the effect of the antibacterial activity of the almond powder of this plant.

\section{Assessment of Drinking Water Supply in Kenge}

\section{Servicing and Drinking Water Management System in Kenge}

The City of Kenge has water supply infrastructures whose management is exclusively granted to REGIDESO, without any legal mechanism of professional, associative and community controls being involved (Figure 2). A recent study found that the majority of respondents $(45.5 \%)$ did not know that they had the right to be involved in managing the water supply in the study area. This was mainly explained by the centralist policies of water supply and sanitation existing since colonial times, the low awareness and dissemination of information on the recent decentralization of the water sector, the failure of village projects -assaini, school-sanitized and university-sanitized, as well as a low level of education of most respondents [3]. It is important to note that, the absence of a public-private partnership at REGIDESO level and the virtual failure of community management of drinking water supply systems in rural areas (village-sanitation projects and school- sanitation) are the basis for continued water rationing for affected populations and the low coverage of water supply estimated at about $34 \%$ between 2010 and 2015, while access to improved sources of drinking water has, in some cases, reached about 57\% in rural areas and $61 \%$ in peri-urban areas in 2015 [3].

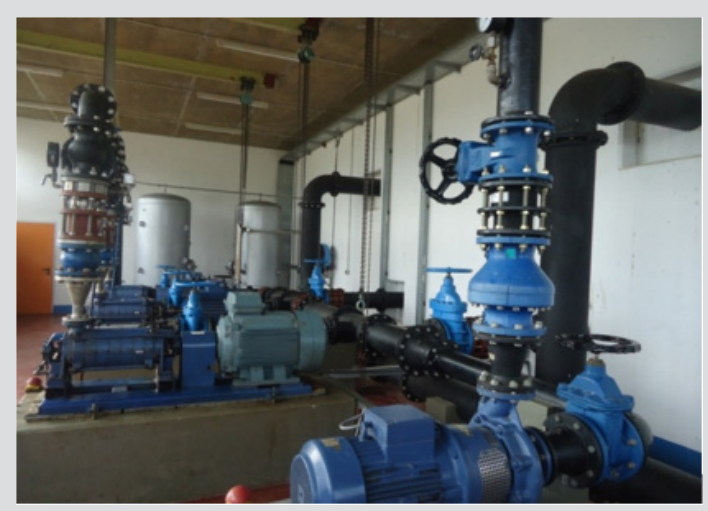

Figure 2: Équipement électromécanique de repompage d'eau de la REGIDESO, Kenge (Auteurs, 2018).

Thus, the vast majority of the population gets their supplies of any water that is easily and freely accessible from unprotected sources (freshwater sources, open wells, rivers and other surface water bodies). However, stagnant rain and swamps are used for purposes other than human consumption (beverage and cooking). Needless to say, water supply systems are critical and critical for social well-being, economic production and growth, and environmental sustainability in all countries [4]. As the human population grows, the water supply is threatened both in quality and quantity because of the high demands on energy, irrigation and industrial production [5]. The urban demand for irrigation and the drainage of municipal and industrial wastewaters start the quality of fresh water available in the wild for human and animal consumption. These contaminated waters pollute rivers and threaten ecosystems. Hence the need for integrated management of water resources in all their different uses, according to socio-economic and environmental objectives, including the achievement of the Sustainable Development Goals (SDGs) [6]. This means that the Congolese government will consciously have to include water resources development in its agenda while placing particular emphasis on collective control over available resources and monitoring the quality of drinking water so as to ensure a systematic allocation of water resources. equitable for all for their sustainable (long-term) use by future generations [7] (UNEP and WHO, 2011).

\section{Monitoring the Quality of Drinking Water}

Water quality monitoring studies aim to explain the inherent and apparent optical properties of specific particles in a water body, including turbidity, conductivity, dissolved oxygen, fluoride, temperature, the potential of hydrogen $(\mathrm{pH})$ as well as the presence 
of algae and microbes (bacteria and viruses). These suspended or dissolved particles in water determine these inherent physical and chemical, biological, and optical properties that are a guarantee of water quality [8].

Monitoring the Physical and Chemical Properties of Water: Long-term monitoring of water quality is the standard and observed measurement in aquatic environments of the state and trends in physical, chemical, biological and optical properties of water. In fact, the quality of water determines its "potability" according to the precise objectives of water production, thanks to the quality biochemical tests (WHO, 1986, 2004). These provide the necessary information on the health and drinking water storage capacity of rivers over a period of time to detect changes in water quality [7,9]. Monitoring of standards such as those issued by WHO allows monitoring of this water quality in springs and taps to detect biological and chemical threats that define the boundary conditions for subsequent treatment of water supply as well as early warning measures deemed necessary in case of unexpected contamination (WHO, 2003). For example, water quality monitoring is a programmed process of sampling, measuring and recording and / or signaling various water features in order to assess water quality (Figure 3).

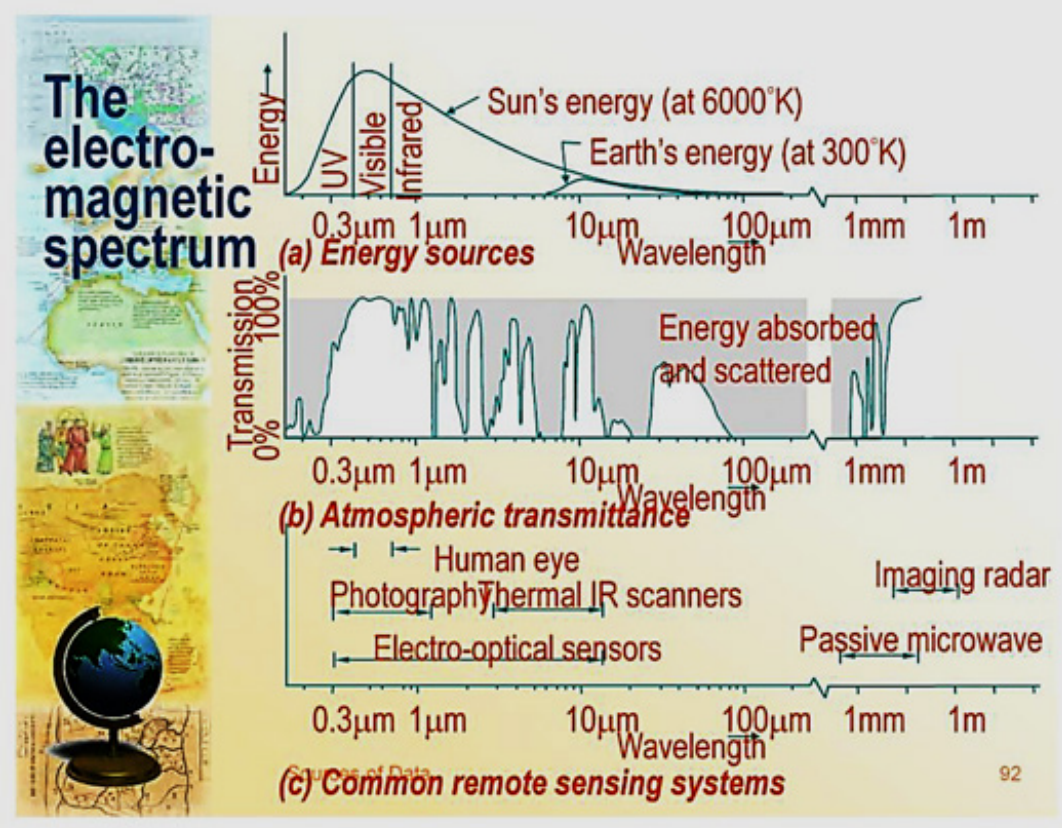

Figure 3: Énergie électromagnétique et systèmes de télédétection (Zhou, 2013).

The quality of the water changes over time as its constituents absorb and reflect the visible light of the sun. The most important constituents reflect sunlight or carry its inherent optical properties such as absorption, diffusion and transfer. These are zooplankton, phytoplankton and their pigments (Chla), suspended particles (MES), colored dissolved organic matter (CDOM), viruses, bacteria and detritus, as well as mineral particles from sediments. erosion $[10,11]$. Their optical behavior and the combined attenuations of all other constituents of water are described by the inherent optical properties (IOP) of water, which define the diffusion and absorption of light in aquatic environments. This alteration of visible light can be spatially controlled and used for monitoring water quality, monitoring biological events such as eutrophication and sediment transport to plan dredging activities. water and water treatment [8]. In addition, water quality monitoring using remote sensing combined with biochemical quality testing of strategic samples collected in situ can play a crucial role in determining the current status of water quality conditions. water in an aquatic ecosystem. It can anticipate, mitigate and even avoid future water disasters [12].

\section{Research Materials and Methods}

\section{Description of the Study Environment}

The City of Kenge is the capital of Kwango Province. It is located at $5^{\circ} \mathrm{S}$ latitude, $17^{\circ}$ East longitude, and an average elevation of 555 $\mathrm{m}$ above sea level [13].The city was built as a relay city between Kinshasa the capital $(275 \mathrm{~km})$ and the city of Kikwit, in the province of Kwilu, on the national road No. 1. Following the classification of van Köppen, Kwango Province in general and the town of Kenge in particular is located in tropical tropical savanna-type AW3 (tropical savana) (Figure 4). The town of Kenge rests on plateaux intersected by deep valleys and hills with sandy soils in a predominantly savannah configuration interspersed with forest galleries along streams (Figure 1 above). Its population is estimated at 183,290 inhabitants and it covers an area of $2,230 \mathrm{~km}^{2}$, a density of 82 inhabitants per square kilometer divided into 15 districts [14]. 


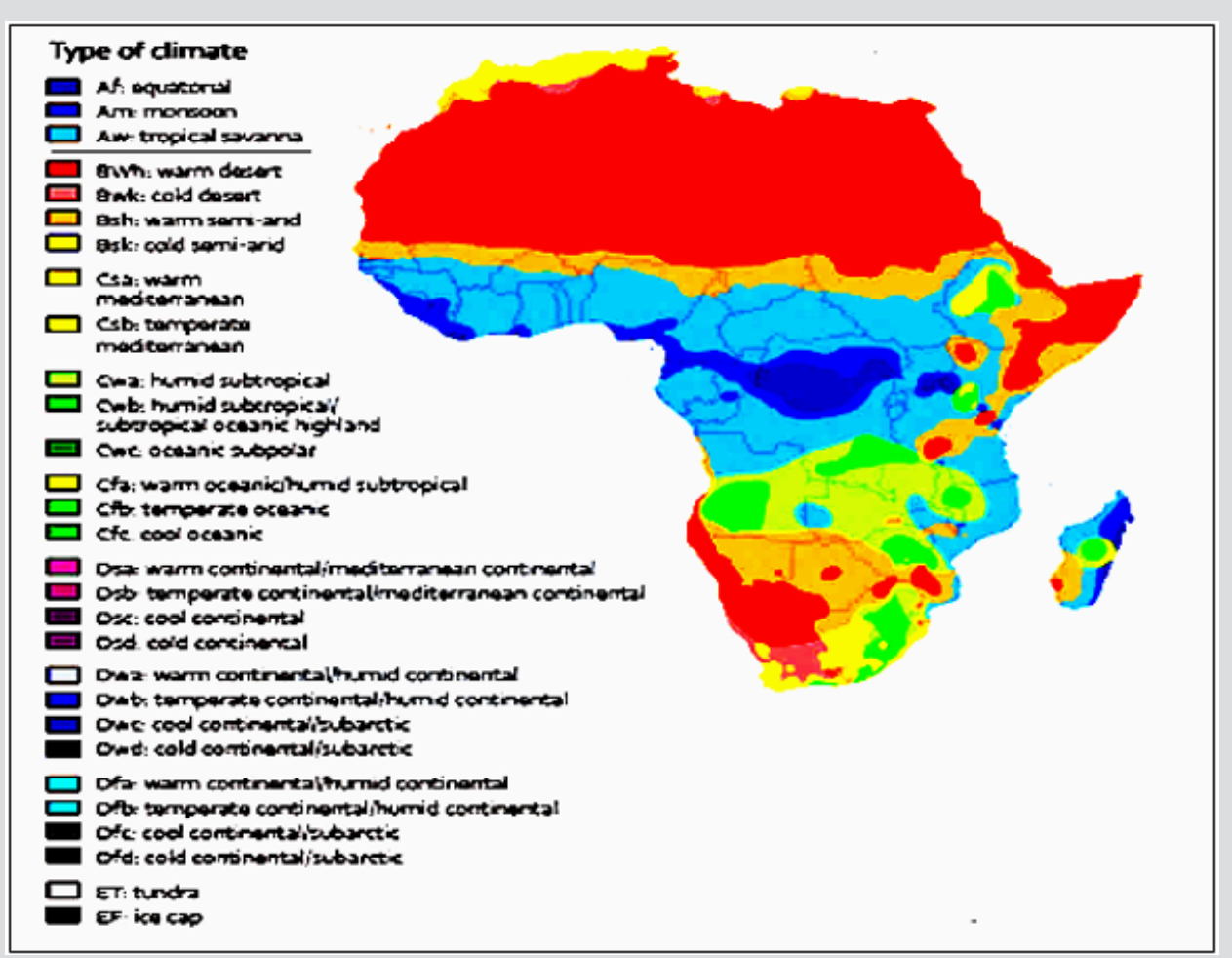

Figure 4: Carte climatologique de l'Afrique selon Van Köppen (Beyene et Luwesi, 2018).

\section{Research Materials}

The plant material used for our study consisted of almonds of Moringa oleifera seeds harvested from the Kenge Savannah. The latter were dried at $40^{\circ} \mathrm{C}$ in a Memmert brand oven and crushed using a mortar and pestle to obtain the powder that was used to prepare extracts for various analyzes in the laboratory MARSAVCO. Three bacterial isolates (Escherichia coli, Salmonella typhi and Staphylococcus aureus) from the bacteriology laboratory of University Clinics Kinshasa (CUK) were used and stored in a Whirlpool brand refrigerator at $4^{\circ} \mathrm{C}$. The following culture media were used for enumeration of Streptococci, Faecal and Total Coliforms, Total Sprouts and Clostridiums: Nutrient Agar or Columbia Agar (PCA), Neomycin Trypcase Sulfite (TSN), and MacConkey. These media were prepared in an Erlenmeyer flask and poured into petri dishes under the Polon Promieniowanie Szkodliwe DlaWzrokvIskory laminar flow hood. A Garmin GPS was used to collect geographic coordinates of water samples from six sites (S1 to S6) including Binene, Five, Lisengi, Mibu, Munoko and Ville (Figure 5).

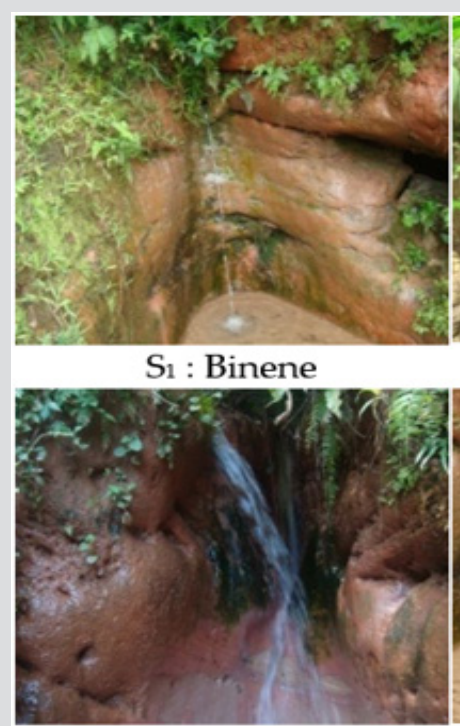

S4: Mibu

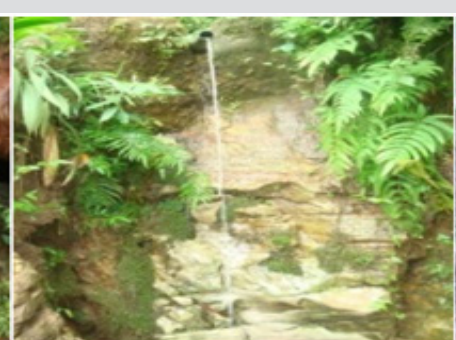

$\mathrm{S}_{2}$ : Cing ans

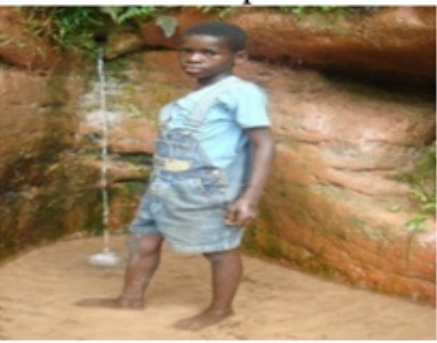

S5: Munoko

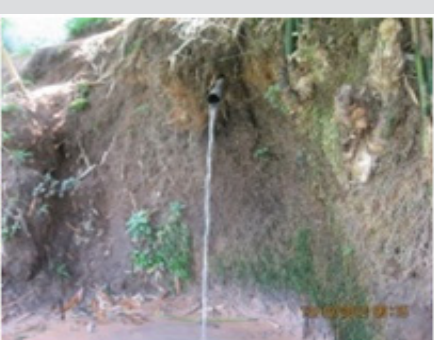

S3: Lisengi

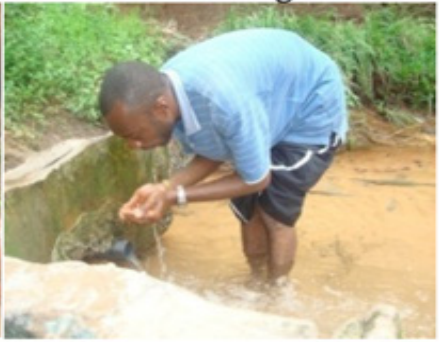

S6: Ville

Figure 5: Échantillons d'eaux prélevés dans les sources de Kenge (Auteurs, 2018). 


\section{Research Methods}

This study is naturally based on an experimentation of the Moringa Oleifera Lam virtues for the treatment of spring water in the City of Kenge and its surroundings. Measurements of temperature, salinity, conductivity, hydrogen potential $(\mathrm{pH})$ and dissolved oxygen $\left(\mathrm{O}_{2}\right)$ were taken at each site using a 340i Multi-parameter analyzer. Chemical screening has identified different chemical and microbiological groups. The chemical analyzes were made from the aqueous and organic phases using the techniques used by Pareck [15]. The microbiological analyzes mainly focused on the technique of enumeration of microorganisms in solid medium during the rainy ( $\mathrm{Pl}$ ) and dry (Se) seasons, with or without the application of the almond powder treatment of Moringa seeds. oleifera Lam. The experimental analysis of the efficacy of M. Oleifera Lam was evaluated across three treatment groups (T1, T2 and T3) versus one control (T0) in the six selected water intake sources. The different treatment doses were prepared at different concentration levels:

a) TO: Control Threshold (Dose-Control)

b) $\mathrm{T} 1$ : Lower threshold (Dose $=187.5 \mu \mathrm{g} / \mathrm{ml}$ )

c) T2: Normal threshold (Dose $=375 \mu \mathrm{g} / \mathrm{ml}$ )

d) T3: Upper threshold (Dose $=562.5 \mu \mathrm{g} / \mathrm{ml}$ )

Then, the researchers proceeded to the preparation of the extracts used for maceration and then frozen them for lyophilization. The disk method and the determination of the Minimal Inhibitory Concentration (C.M.I) were used for the evaluation of the antibacterial activity. Statistical tools were finally used to analyze the data. It consisted mainly of descriptive statistics of the physical and biochemical properties of previously measured treatments, including temperature, conductivity, hydrogen potential $(\mathrm{pH})$ and dissolved oxygen, N03-, CO-, HCO3-, SO32 -, P043-, total hardness, Cl-, Alkalinity, $\mathrm{T} \Delta \mathrm{s}$, and salinity. Then, the analysis of variance (ANOVA) was tested at $5 \%$ significance level $(\mathrm{P}<0.05)$ using MSTAT-C Software [16]. ANOVA was used to estimate significant levels of water quality between the six sampling sources (S1, S2, S3, S4, S5 and S6), before and after the application of the three phytochemical treatments (T1, T2 and T3) vis-à-vis the control dose (T0).
The final result was interpreted in terms of the variation of significant differences in the improvement of the biochemical quality of water for human consumption as a result of Al Oleifera Lam's almond powder treatment. the residual presence or loss of several pollutants and sediments in the treated water. This analysis also made it possible to observe the signs of degradation of these water sources and their watersheds due to the negative impact of erosion processes and the sustained pollution of water by human, animal, agricultural and industrial waste. This has made it possible to recommend Al Oleifera Lam Almond Powder as one of the Best Management Practices (BMPs) to ensure the quality of drinking water for human use and to reduce incidence of waterborne diseases in the City of Kenge.

\section{Results and Discussion}

\section{Results of the Study}

Assessment of Physico-Chemical Parameters: The results for the temperature, $\mathrm{pH}$, conductivity, and dissolved oxygen in water collected from the Kenge City Springs are shown in Figure 6. Statistically speaking, the values measured for the 4 parameters do not show a significant difference between the different sources at the 5\% significance level. However, an examination of this figure shows that the temperature values vary from one source to another. For the analyzed sources, the calculated average is $26.3^{\circ} \mathrm{C}$ and the variances are not significant, since all the sources have values that oscillate between 25.7 and $27.6^{\circ} \mathrm{C}$. As for $\mathrm{pH}$, its values show that all these sources are acidic $(\mathrm{pH}<7)$ with an average of 5.6. Only sources S2 and S6 have values below average, respectively 4.9 and 5. As for the conductivity, it varies between 15 and $30 \mu \mathrm{s} / \mathrm{cm}$. The Binene and Lisengi sources showed values below 20 $\mu$ s / cm while the estimated values for the Munoko, Five-year, City, and Mibu sources ranged from 27, 25, 21, and $20 \mu \mathrm{s} / \mathrm{cm}$, respectively. Finally, the dissolved $\mathrm{O}_{2}$ was greater than $1 \mathrm{mg} / \mathrm{l}$ for all sources, except for the source of Five years whose value was less than 1 , or $0.83 \mathrm{mg} / \mathrm{l}$. Table 1 presents the results of other physico-chemical parameters related to surface water quality (NO3-, SO32-, total hardness, $\mathrm{Cl}$-, Alkalinity, T $\Delta$ s, and salinity).

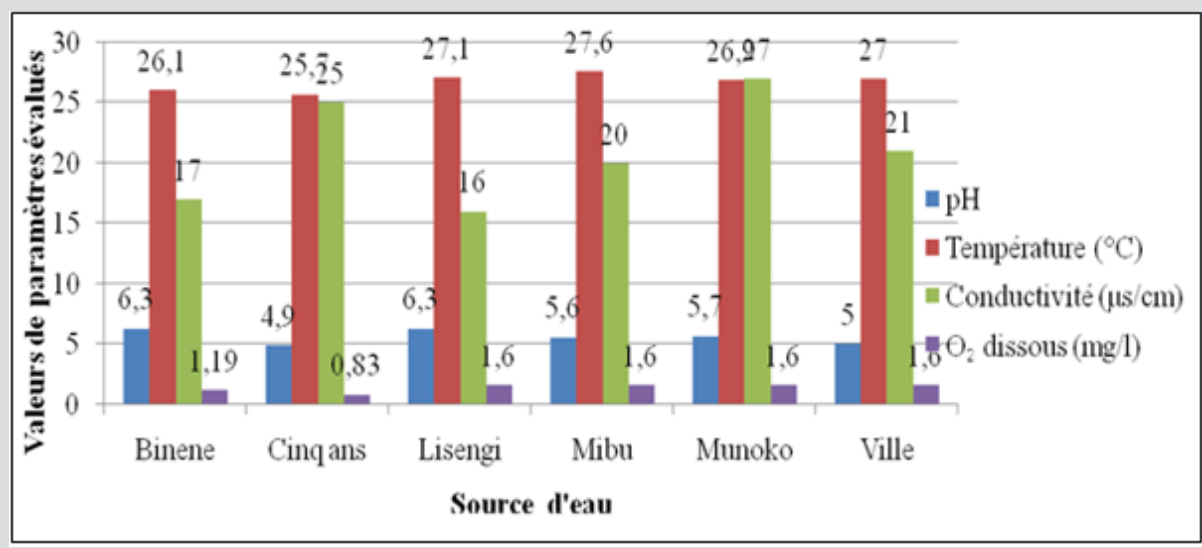

Figure 6: Valeurs de paramètres physico-chimiques des sources de Kenge(Auteurs, 2018). 
Table 1: Other physico-chemical parameters of water quality from Kenge.

\begin{tabular}{|c|c|c|c|c|c|c|c|}
\hline \multirow{2}{*}{ Sources } & \multicolumn{7}{|c|}{ Autre sparamètres } \\
\hline & $\mathrm{PO}_{4}{ }^{3}-(\mathrm{mg} / \mathrm{l})$ & $\mathrm{SO}_{3}{ }^{2}-(\mathrm{mg} / \mathrm{l})$ & Dureté totale (mg/l) & $\mathrm{Cl}-(\mathrm{mg} / \mathrm{l})$ & Alcalinité (mg/l) & $\mathrm{T} \Delta \mathrm{s}(\mathrm{mg} / \mathrm{l})$ & Salinité (mg/l) (ppt) \\
\hline $\mathrm{S}_{1}$ & 1,55 & 4,22 & 1,9 & 4,8 & 21,8 & 42,5 & 0,04 \\
\hline $\mathrm{S}_{2}$ & 0 & 1,90 & 0,5 & 0,9 & 18,0 & 43,6 & 0,04 \\
\hline $\mathrm{S}_{3}$ & 1,55 & 3,93 & 2,0 & 2,0 & 21,0 & 39,5 & 0,04 \\
\hline $\mathrm{S}_{4}$ & 1,55 & 5,88 & 2,7 & 2,6 & 21,5 & 38,8 & 0,04 \\
\hline $\mathrm{S}_{5}$ & 1,55 & 1,46 & 0,8 & 0,5 & 20,0 & 47,7 & 0,05 \\
\hline $\mathrm{S}_{6}$ & 0 & 1,58 & 0,5 & 0,5 & 19,5 & 33,8 & 0,03 \\
\hline
\end{tabular}

Source: Analyses effectuées au laboratoire de MARSAVCO (Auteurs, 2018).

\section{Microbiological Analyzes}

Enumeration of bacterial germs in sources without $M$. Oleifera Lam powder: Figure 7 presents a count of germs found in samples taken from water sources during the dry season, without the almond powder of Moringa Oleifera Lam seeds being applied (Table 1) \& (Figure 7). Statistically, the ANOVA test shows a significant difference in the enumerated total seed counts $(p<0.05)$ between all water sources and sources S4 (Mibu) and S5 (Munoko). Germs counted at source Munoko (S5) reveal a more acute pollution is 99.5 for streptococcus. No significant difference was detected for the presence of total coliforms and the rest of the germs in all sources. Figure 8 presents a count of germs found in samples collected from Kenge water sources during the rainy season, without the almond powder of Moringa Oleifera Lam seeds being applied.
Statistically, the ANOVA test ( $\mathrm{p}<0.05$ ) showed no significant difference between the enumerated organisms (total coliforms, streptococci and total germs) for some sources. The counted germs reveal a more severe pollution at the source City (S6) or 82.50 for streptococcus. However, a significant difference in total sprouts was found between the source City (S6) and the other sources, the source S6 recording 130 total germs. Comparing the populations of sprouts observed during the two seasons (rainy and dry), no significant difference appeared. Nevertheless, the presence of bacterial germs in the water indicates that several sprouts swarm in all sources during the dry season, especially for total coliforms and streptococci, while total sprouts are more numerous during the spring season. rain. Note however that the presence of certain germs, such as faecal coliforms and Clostridium, was not at all apparent; no trace occurred on all of the sources collected (Figure 8).

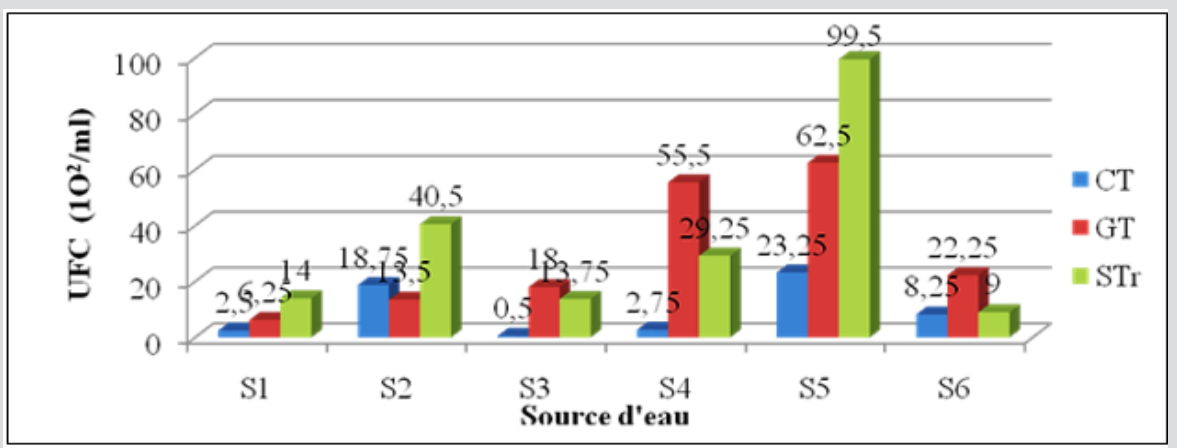

Figure 7: Population of coliforms and bacteria counted during the dry season (Authors 2018).

CT : total coliforms GT : total germs.

UFC : STr: Streptococcal colony forming unit.

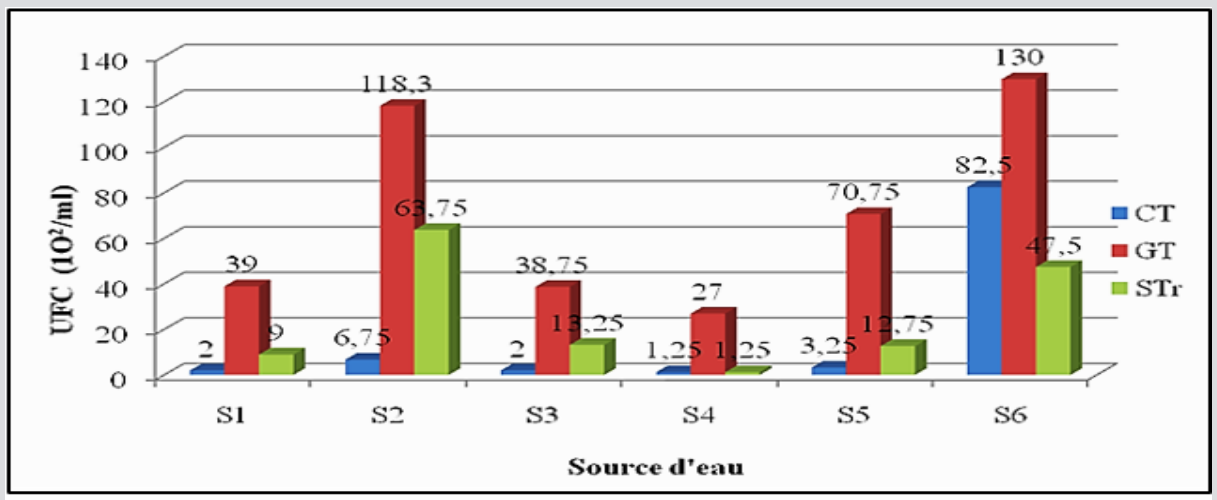

Figure 8: Total coliform, total sprout and streptococcal population during the rain season in Kenge water sources (Authors, 2018). 
Enumeration of Bacterial Germs in Sources after Application of M. Oleifera Lam: Another bacterial count was made during the two seasons in selected water sources after the application of different doses of almond powder from Moringa Oleifera Lam seeds. The results of this count are shown in Figures 9-12. Figure 9 shows the degree of bacterial load, especially total germs, after treatment with different doses of Moringa Oleifera Lam in Kenge springs during the rainy season (Figure 9). The analysis of variance (ANOVA) performed by the software MSTAT-Crévèle significant differences between treatments doses of M. Oleifera Lam in different sources. By comparing the treatments applied (T1,
$\mathrm{T} 2, \mathrm{~T} 3$ ) with the control treatment (T0), the bacterial load of total germs decreases in effectiveness according to the doses of Moringa Oleifera Lam applied (T0> T1 > T2 > T3). However, by comparing the responses of the different water sources, we note that the sources S2, S4, S5, and S6 are significantly different from the sources S1 and S3 for the dose T0, the dose of T1 and the dose of T2. S2 and S5 sources at the T3 dose are significantly different from the S1, S3 and S6 sources. Finally, there is no significant difference between the S2, S4 and S5 sources compared to the T3 dose. Nevertheless, the source $\mathrm{S} 5$ is the only one that is more polluted for the set of sources.

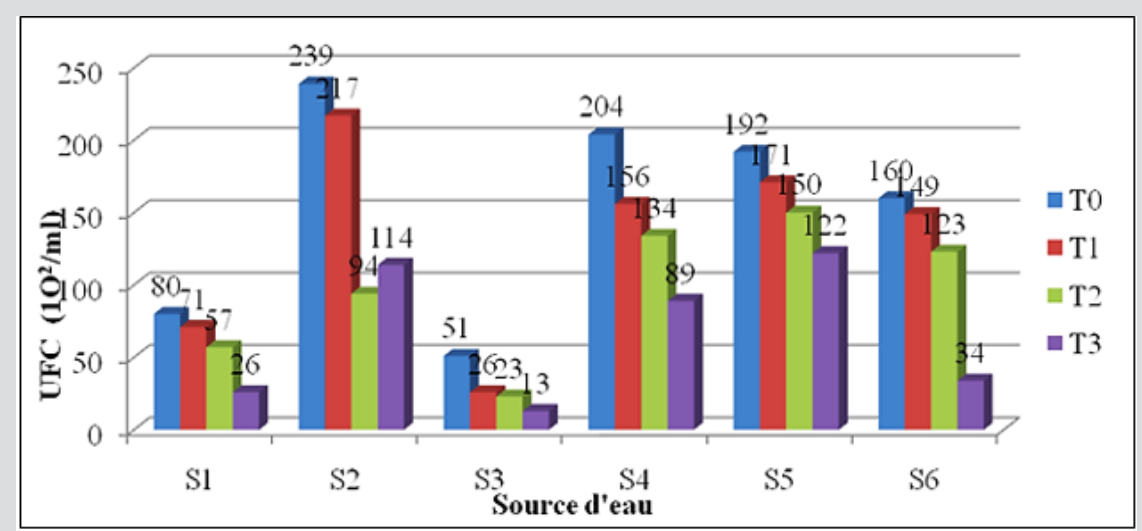

Figure 9: Total sprout population in Kenge water sources during the rainy season after application of doses of M. Oleifera Lam (Authors, 2018).

T0 : Control T2 : Normal dose $=375 \mu \mathrm{g} / \mathrm{ml}$.

$\mathrm{T} 1$ : Lower dose $=187.5 \mu \mathrm{g} / \mathrm{ml} \mathrm{T3}:$ Higher dose $=562.5 \mu \mathrm{g} / \mathrm{ml}$.

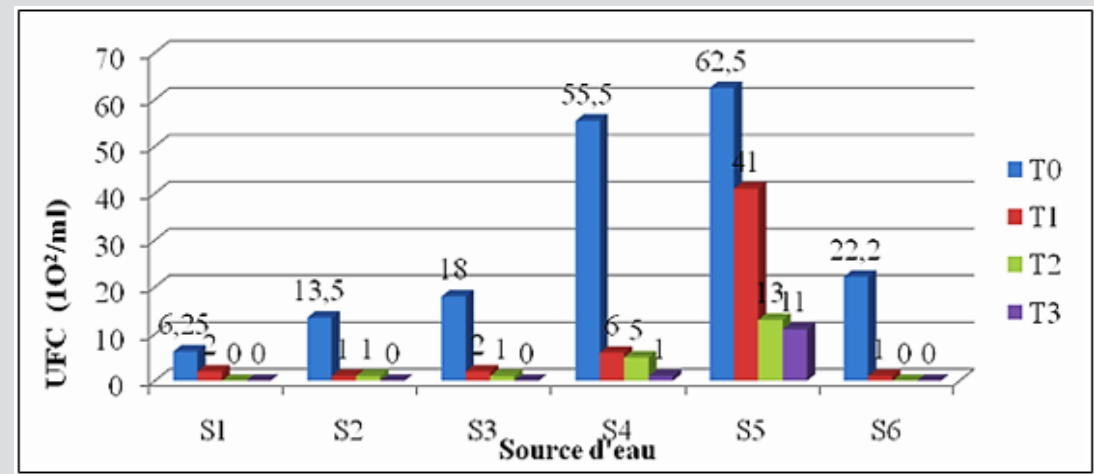

Figure 10: Total sprout population in Kenge water sources during the dry season after application of doses of M. Oleifera Lam (Authors, 2018).

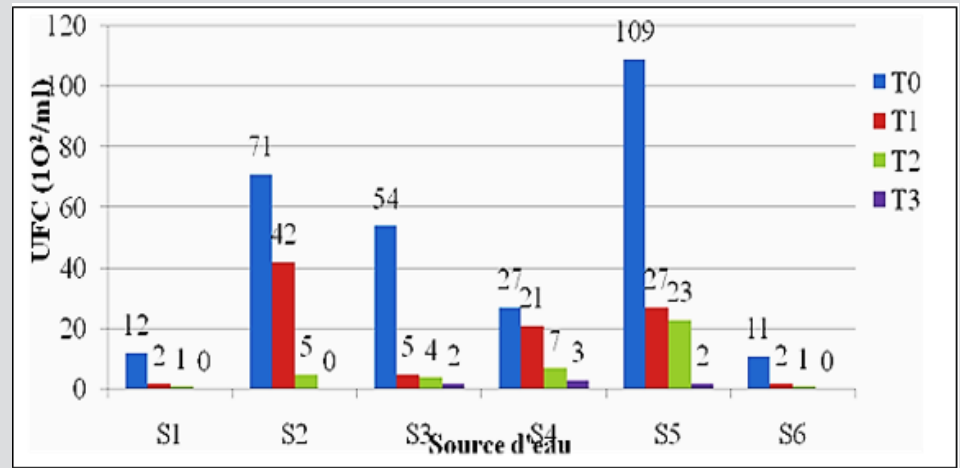

Figure 11: Total coliform population in Kenge water sources during the dry season after application of doses of M. Oleifera Lam (Authors, 2018). 


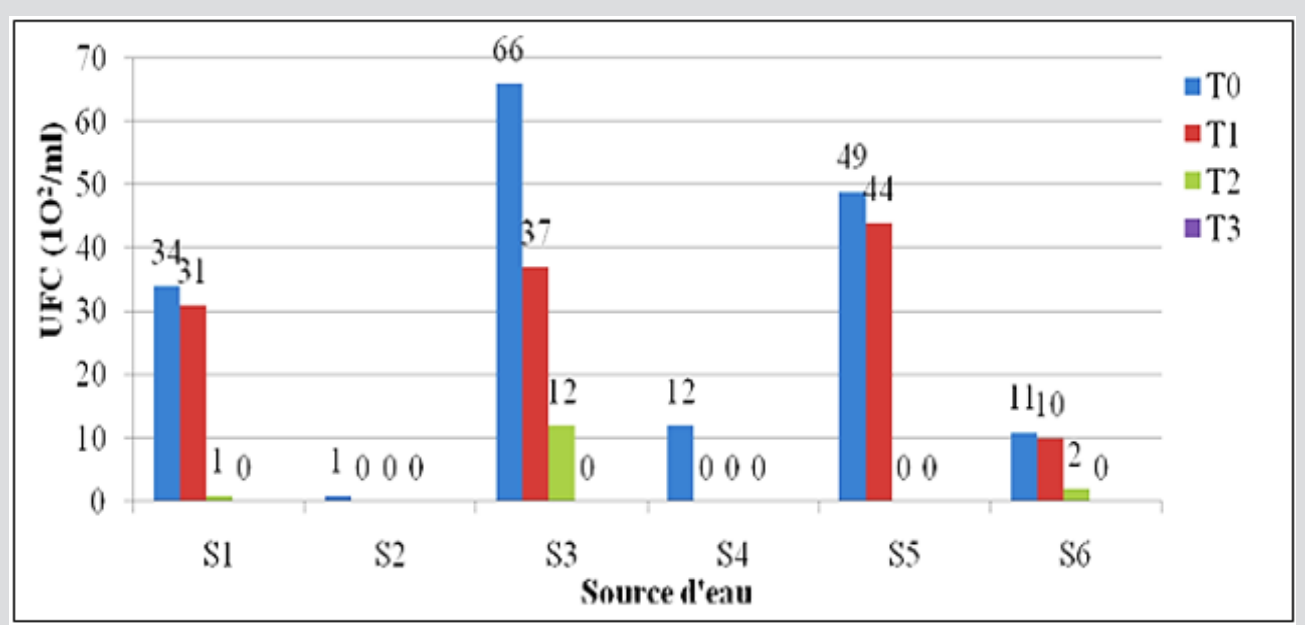

Figure 12: Total coliform populations counted during the rainy season in springs after applying doses of M. Oleifera Lam (Authors, 2018).

It can be seen from Figure 10 that only the S5 source is more polluted and significantly different from the rest of the sources S1, S2, S3, S4, S6 for treatment doses T0, T1, T2, T3. The source S4 is also different from the source $\mathrm{S} 1$ as regards the dose of TO (Figure 10). ANOVA indicates that during the dry season, statistically significant differences in bacterial loads were observed between different treatment doses and sources. The doses applied to the different treatments showed a decrease in mean bacterial load for all sources with $\mathrm{T} 0>\mathrm{T} 1>\mathrm{T} 2>\mathrm{T} 3$. Figure 11 shows, on the one hand, that no statistically significant difference exists between the different treatments of Moringa Oleifera Lam and that, on the other hand, there are significant differences at different doses between Kenge water sources (Figure 11). The analysis of the differences between the sources according to the applied doses indicates that the source S5 is the most polluted and significantly different from the sources $\mathrm{S} 1$, S4 and S6 for the control treatment (T0). Source S5 is also different from all sources for T2 treatment. However, no significant difference was reported between all sources for $\mathrm{T} 3$ and $\mathrm{T} 1$ treatment, with the exception of source S2 for T1 treatment. Nevertheless, the analysis confirms that the bacterial load in the sources decreases with the applied doses of M. oléifera Lam (T0> T1 > T2> T3).
The analysis of differences in total coliform populations counted during the rainy season in the sources (Figure 12) as a function of applied Oleifera Lam doses shows that only the S5 source is more polluted and significantly different from the S1, S4 and S1 sources. S6 for treatment T0. The source S5 remains different from all the other sources after the application of the processing T2. No significant difference has been detected between all the sources except for the sources S3 (case of T0), S2 and S4 (case of T1) and the sources S1, S2, S4, S5 and S6 (case of T2). Finally, there is no significant difference between the sources with respect to the dose of T3; only the source S2 is less polluted on all of the doses applied (Figure 12). ANOVA shows statistically significant differences between sources, on the one hand and no statistically significant difference between treatments of Moringa Oleifera Lam doses in the sources. And, the bacterial load represented by total coliforms decreases with the efficacy of the doses of M. Oleifera Lam applied according to the treatments and this in comparison with the control treatment ( $\mathrm{T} 0>\mathrm{T} 1>\mathrm{T} 2>\mathrm{T} 3$ ). In summary, enumeration during the rainy season for total sprouts clearly expresses a higher bacterial load than dry season sprouts and total coliforms during the two seasons (Figure 13). Treatment with a dose of Moringa Oleifera Lam is carried out in a growing way (Figure 13).

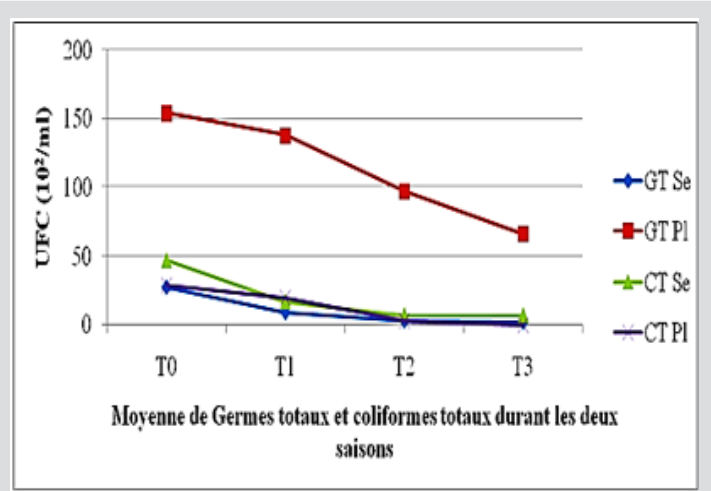

Figure 13: Summary of total germs and total coliforms counted during the two seasons (Authors, 2018). GT : Total sprouts Pl : Rainy season. CT : Total Coliforms Se : Seasons. 
Phytochemical Analysis: The identification of the major chemical groups contained in the seed kernel of M. Oleifera Lam harvested in Kenge reveals the only presence of alkaloids. Table 2 shows the results of this chemical screening of the almond powder of Moringa seeds. Oleifera Lam harvested in the City of Kenge (Table 2).

Table 2: Chemical Screening of the almond powder of the seeds of Mr. Oleifera Lam.

\begin{tabular}{|c|c|c|}
\hline Screening Chimique & Réactifs & Résultats \\
\hline \multicolumn{3}{|c|}{ Extraits Aqueux } \\
\hline Alcaloïdes & Drangendroff & + \\
\hline Anthocyanes & $\mathrm{HCl}$ à $20 \%$ & - \\
\hline Quinones libres & Borntrager & - \\
\hline Saponines & Test de la mousse & - \\
\hline Tanins & $\mathrm{Fecl}_{3}$ à $2 \%$ & - \\
\hline \multicolumn{3}{|c|}{ Extrait Organique } \\
\hline Quinones liée & & - \\
\hline \multicolumn{3}{|c|}{ Extrait Alcoolique } \\
\hline Flavonoïdes & Shinonda & - \\
\hline
\end{tabular}

Source: CUK Laboratory Analyzes (Authors, 2018).

(+) Presence

\section{(-) Absence}

Assessment of Antibacterial Activity: The evaluation of the biological activity of the aqueous extracts of the seed kernel powder of Moringa Oleifera Lam first focused on the determination of the minimal inhibitory concentration (MIC) of variant bacterial strains from 7.83 to $2500 \mu \mathrm{g} / \mu \mathrm{l}$ of the aqueous extract of M. oleifera Lam (Table 3). The results shown in Table 4 present the evaluation of the biological activity of the aqueous extracts of M. Oleifera Lam seed kernel powder on the basis of the diameter of the growth inhibition zone of the bacterial strains tested. In general, the diameters of inhibition increase with the concentration of the aqueous extracts (Table 4). Based on the results in Table 4, it appears that only strains of Salmonella typhi and Staphylococcus aureus are Table 3: Strains susceptibility to M. Oleifera Lam extracts. sensitive to extracts of M. Oleifera Lam, whereas Escherichia coli strains are resistant up to $2,000 \mu \mathrm{g} / \mu \mathrm{l}$ of concentration. It can then be concluded that the determination of the susceptibility of the strains by the diffusion method presents an important zone with Staphylococcus aureus strains (concentration of $1500 \mu \mathrm{g}$ / $\mathrm{ml}$, on average $21 \mathrm{~mm}$ in diameter) and strains of Salmonella typhi (concentrations ranging from from 1.500 to $93.75 \mu \mathrm{g} / \mu \mathrm{l}$, which is $16 \mathrm{~mm}$ in diameter on average). But resistance is present at the extracts of 48.875 and $23.45 \mu \mathrm{g} / \mathrm{ml}$ for these two strains. Escherichia coli strains exhibit sensitivity to aqueous extracts of the seed kernel powder of M. Oleifera Lam from a concentration of 1500 to $187.5 \mu \mathrm{g} / \mathrm{ml}$.

\begin{tabular}{|c|c|c|c|c|c|c|c|c|c|c|c|c|}
\hline \multirow{2}{*}{ Germes Bactériens } & \multirow{2}{*}{ Isolats } & \multicolumn{11}{|c|}{ Concentration testée à différentes doses $(\mu \mathrm{g} / \mathrm{ml})$. } \\
\hline & & 2500 & 2000 & 1500 & 1000 & 500 & 250 & 125 & 62,5 & 31,25 & 15,63 & 7,83 \\
\hline \multirow{2}{*}{ Escherichia coli } & $\mathrm{e}_{1}$ & - & + & + & + & + & + & + & + & + & + & + \\
\hline & $\mathrm{e}_{2}$ & - & + & + & + & + & + & + & + & + & + & + \\
\hline \multirow{2}{*}{ Salmonella typhi } & $\mathrm{s}_{1}$ & - & - & - & - & - & - & & - & + & + & + \\
\hline & $\mathrm{s}_{2}$ & - & - & - & - & - & - & - & - & + & + & + \\
\hline \multirow{2}{*}{ Staphylococcus aureus } & $\mathrm{st}_{1}$ & - & - & - & - & - & - & - & + & + & + & + \\
\hline & $\mathrm{st}_{2}$ & - & - & - & - & - & - & + & + & + & + & + \\
\hline
\end{tabular}

Source: CUK Laboratory Analyzes (Authors, 2018).

$\mathrm{e}_{1}, \mathrm{e}_{2}$ : Escherichia coli 1 and $2(+)$ Presence of bacterial growth

$\mathrm{st}_{1}, \mathrm{st}_{2}$ : Staphylococcus aureus 1 and 2 (-) Absence of bacterial growth

$\mathrm{s}_{1}, \mathrm{~s}_{2}$ : Salmonella typhi 1 and 2

Table 4: Antibacterial activity of Moringa Oleifera Lam.

\begin{tabular}{|c|c|c|c|c|c|c|c|c|}
\hline \multirow{3}{*}{ Souches } & & \multicolumn{7}{|c|}{ Diamètre de zone d'inhibition sur les différents germes (mm) } \\
\hline & & \multicolumn{7}{|c|}{ Concentrations d'extrait de la poudre de M. oleifera $(\mu \mathrm{g} / \mu \mathrm{l})$} \\
\hline & & 1500 & 750 & 375 & 187,25 & 93,75 & 48,875 & 23,45 \\
\hline \multirow{2}{*}{ Escherichia coli } & $\mathrm{e}_{1}$ & 10 & 8 & 7 & 6 & - & - & - \\
\hline & $\mathrm{e}_{2}$ & 10 & 8 & 7 & 6 & - & - & - \\
\hline
\end{tabular}




\begin{tabular}{|c|c|c|c|c|c|c|c|}
\hline \multirow{2}{*}{ Salmonella typhi } & $\mathrm{s}_{1}$ & 15 & 12 & 10 & 7 & - \\
\cline { 2 - 7 } & $\mathrm{s}_{2}$ & 17 & 11 & 8 & 7 & - \\
\hline \multirow{2}{*}{ Staphylococcus aureus } & $\mathrm{st}_{1}$ & 20 & 14 & 12 & 12 & - \\
\cline { 2 - 8 } & $\mathrm{st}_{2}$ & 22 & 20 & 14 & 10 & - \\
\hline
\end{tabular}

Source: CUK Laboratory Analyzes (Authors, 2018).

(Value): Diameter of the inhibition zone around disks impregnated with extracts

$(-)$ : Absence of the inhibition zone around disks impregnated with extracts

\section{Discussion of Results}

Physico-Chemical Parameters: The experimental conditions of the physicochemical parameters of the surface water taken from the various sources of the City of Kenge indicate that the 6 sources meet the standards of a drinking water, except for the $\mathrm{pH}$ which was considered to be rather too acidic (average $<7$ ). In general, the most remarkable physicochemical parameters were P043-, SO32-, total hardness, $\mathrm{Cl}-$, alkalinity, salinity, $\mathrm{pH}$, temperature, conductivity and dissolved oxygen as confirmed by Aminot and Kerouel (2004).). Some parameters affecting water quality yielded averages of 5.6 (for $\mathrm{pH}$ ), $26.7^{\circ} \mathrm{C}$ (for temperature), $21 \mu \mathrm{s} / \mathrm{cm}$ (for conductivity) and $1.16 \mathrm{mg} / \mathrm{l}$ (for dissolved oxygen). The highest $\mathrm{pH}$ values have been reported in S1 and S3 sources. This could be justified by the type of equipment used, the ecological positions of the water sources and their exposure to light, in addition to the geological specificities of the water sources. source rocks from these sources.

These phenomena have been observed by Musibono [17], Malik and Hamdi [18], and Salama and Verhoef [8] who confirmed the effect of sunlight on some physical parameters of spring waters and their acidity during the rainy season. With increased season variability and climate change, more acid rain can be expected and thus the effectiveness of most traditional surface water treatment techniques will be reduced [3]. By comparing the bacteriological values of the water quality of the sources of the City of Kenge with the standards of the European Union and those of the WHO, we note that these sources contain a significant number of microbial populations, presented in the different (Figures 1-13) previously illustrated. This could be justified by the flow of wastewater and pollutants from the soil, slopes, erosions, and hygienic facilities that are upstream of each source.

These results are consistent with those found by Folkard [19], Koffi [20], WHO (2004, 2006 and 2010), who state that surface waters are the main sources used in rural and peri-urban areas (villages and cities). ) to provide food for households and for other uses. The quality of these waters depends on the nature of the soil, the regime of rain and other precipitations, the surrounding vegetation, and especially the proximity of agglomerations. Regarding the effectiveness of the kernel kernel of M. Oleifera Lam, the different doses showed sufficiently effective in reducing the bacterial population to different superficial sources of Kenge. These results are consistent with those of Faby et al. (1993) cited by Chantrel and saint sauveur [21] who suggested that Moringa Oleifera Lam pow- der does not seem to replace alumina sulphate but the two coagulants put together appear more effective and greatly reduce the rate of bacteria including the total and faecal coliforms as well as faecal streptococci that are sometimes not even identified.

Phytochemical Analysis: The major chemical groups presumed to be endowed with very prominent pharmacodynamic properties have been described after the phytochemical screening of the seed kernel powder of Moringa Oleifera Lam. The qualitative analysis of this powder indicates that anthocyanins, free quinones, saponins, tannins, flavonoids, bound quinones and terpenoid as well as steroids are absent; only alkaloids are present (Koffiet al, 2009). These results are confirmed by Folkard [19], Foild [22], Fuglie [23] and Anwar et al. [24] that states leaves, pods, seeds and young branches of Moringa Oleifera Lam are consumed and contain no toxic substances or tannins in large quantities. This virtual absence of all chemical groups could be explained by, among other things, the origin, the season and the time of day for the harvest, the habitat, but also the physiology of the plant [25].

Evaluation of Antibacterial Activity: It appears from the analysis of the biological activity of drugs or extracts derived from the almond seeds of Moringa Oleifera Lam that the strains of bacteria used are sensitive to the powder of kernel seeds of Mr. Oleifera Lam based Inhibition zone diameters. Since strains of Staphylococcus aureus and Salmonella typhi, respectively, have longer inhibition zone diameter averages of $21 \mathrm{~mm}$ and $16 \mathrm{~mm}$, they are, of course, more sensitive than Escherichia coli strains of average inhibition zone is close to $10 \mathrm{~mm}$. In general, for all strains, the inhibition zone diameters observed vary as a function of the concentration of the powder used (Leclercet 1995). Ericsson \& Sherries [26] justify the reduction of the inhibition zone diameter of the Escherichia coli strain from $93.75 \mu \mathrm{g}$ by multiple factors which generally modify, in particular, the nature of the culture medium, the incubation time, the diffusion power of the powder and the number of germs. The almond extracts of the seeds of $\mathrm{M}$. Oleifera Lam thus have a proven antibacterial action on gram + and gram- bacteria. But the sensitivity of tested germs should vary not only with the concentration of the powder but also and especially with the bacterial species.

The tests performed in this study did not allow an accurate determination of minimum inhibitory concentrations (MICs) but were in agreement with those obtained by the disc method and allowed more classification of the strains used by their order of 
sensitivity. Escherichia coli, Salmonella typhi, and Staphylococcus aureus), as evidenced by the CMI estimates shown below:

(i) Escherichia coli: C.M.I would be $>2000$ and $\leq 2500 \mu \mathrm{g} /$ $\mathrm{ml}$.

(ii) Salmonella typhi: C.M.I would be $>62.5$ and $\leq 125 \mu \mathrm{g} / \mathrm{ml}$ but also $>125$ and $\leq 250 \mu \mathrm{g} / \mathrm{ml}$.

(iii) Staphylococcus aureus: C.M.I would be $>31.25$ and $\leq 62.5$ $\mu \mathrm{g} / \mathrm{ml}$

These results corroborate those made in 2005 by a Chinese study that demonstrated the very potent antibacterial action of M. Oleifera Lam and his ability to clarify water by coagulation [27]. Studies conducted by ECHO staff in 1985, 2002, and 2007 confirmed the effectiveness of the almond seed of Moringa oleifera Lam against Staphyloccocus aureus and Pseudomonas aeroginosa bacteria that attack the skin (Leclercet al These studies also indicated that the seed extract of M. oléifera has the ability to inhibit the growth of Staphylococcus aureus and Bacillus substilus but not those of Escherichia coli and Pseudomonas aeroginosa (Folkard, 1997, Foild [22], Fuglie [23], Doughari JH [10], and the websites phytomania.com and moringanews.com). These antibacterial virtues found in the seed kernel powder of M. Oleifera Lam, which showed only alkaloids as a chemical group, are in contradiction with the different chemical groups that can be attributed to the antiseptic properties (tannins), detergents (saponins), antibiotics and antifungals (quinones) of the organs studied [28].

\section{Conclusion and Recommendations}

\section{Conclusion}

The purpose of this study was to evaluate the physicochemical and microbiological qualities of Moringa seed kernel powder. Oleifera Lam determines its effectiveness in surface water treatment in the City of Kenge. It was particularly important to measure physico-chemical parameters to certify the effectiveness of this treatment on the quality of surface water. By way of illustration, the $\mathrm{pH}$ of the various water sources has been found to be acidic and inferior to WHO standards, as well as their temperatures which, in principle, should be around $25^{\circ} \mathrm{C}$ (WHO, 1994), while their conductivity and dissolved $\mathrm{O}_{2}$ varied by source. With the increased variability of the seasons due to climate change, more acid rain could be expected and thus the reduction in efficiency of most traditional surface water treatment techniques [3]. The study has clearly demonstrated the effectiveness of plant extracts of the almond Oleifera Lam in disinfection of water. Phytochemical screening first revealed the presence of alkaloids which represent the only chemical group encountered in this plant material. Seed extracts from the plant showed demonstrated antibacterial activity [10], Koffi [20].

A zone of antibacterial activity of the order of 21, 16 and $10 \mathrm{~mm}$ in diameter was detected respectively for Staphylococcus aureus, Salmonella typhi and Escherichia coli. The efficacy of these almond seed doses of M. Oleifera Lam has been demonstrated during the rainy season samples where significant differences were observed between treatments and water sources. The population of total sprouts and total coliforms that have been reported may be justified by the topography of some sources and biological pollutants mainly from animal and human excrement, plant debris, and runoff water entering the river. surface of the earth. This experimental study shows that the seed kernel powder Moringa Oleifera Lam influences the effectiveness of the microbiological quality of water by reducing the number of bacterial germs. Fecal contamination indicators (fecal coliforms / gram-, fecal enterococci / gram +, Clostridium sulphite-reducing agent, etc.) have made it possible to evaluate the microbiological quality of water by revealing the presence or absence of pathogens or indicator microorganisms. But the effectiveness of Moringa Oleifera Lam treatment may depend on the nature of the seeds, the soil around the springs or where the tree is grown and the origin of the tree [29-35].

\section{Recommendations}

Given the interest of this study in the effectiveness of the seed kernel of M. Oleifera Lam on the physico-chemical and microbiological quality of surface waters and its biological activity, it is recommended that future researchers complete these studies. research by experimenting with several other detection techniques, including chromatography and spectrophotometry to isolate a molecule derived from the kernel from the seeds of M. Oleifera Lam with flocculating properties, in order to obtain an effective flocculant can replace imported chemicals (iron chlorides and others). Further research is needed to significantly improve phytochemical disinfection methods for water, which is increasingly used in developing countries through the use of Moringa Oleifera Lam seed kernel reduce the number of bacterial germs often found in our rivers and water sources. The application of Moringa Oleifera Lam seed kernels in the disinfection of tap water and bottled water could be an alternative to chlorine, aluminum sulphate and other similar products that would cost expensive and would be rare in rural areas. In short, the seeds of M. Oleifera Lam can be used effectively to produce drinking water on a family scale [36-44].

\section{References}

1. Musibono DE (1992) Qualité de l'eau et aquaculture; une approche d'écodéveloppement. Kinshasa: Editions MTD Engineering, pp. 160.

2. Kiyombo M (2006) Éléments d'hygiène et salubrité du milieu. Mémoire de DEA. Kinshasa: UNIKIN, Faculté de Médecine, École de Santé.

3. Kapende JK, Et Luwesi CN (2018) Analyse multivariée discriminante de la malnutrition chronique au cours de la petite enfance dans la Province du Kwango (2013-2014). Health-Environment Sustainability Journal 7(1): 160-177.

4. (2015) GWP [Global Water Partnership] (2015) Integrated Water Resources Management in Eastern Africa: Coping with 'Complex Hydrology'. Technical Focus Papers (TFP) No 7. Stockholm: Elanders.

5. Wells DE, Cofino WP (1995) A model for marine environmental monitoring. Pure and Applied Chemistry 72: 1453-1460.

6. RKNOW (2016) Knowledge for SDG Action in West Asia and North Africa: R-KNOW Water Governance Best Practices within the Water, 
Energy, Food and Climate Change Nexus. Gland, Switzerland and Amman, Jordan: IUCN. Xii, P. 78.

7. Lufwila VF (2003) Gestion des ressources en eaux souterraines dans la zone des collines de la ville de Kinshasa (Mont-Amba, Mont-Ngafula et Kimuenza): Evaluation qualitative de la ressource. Mémoire de DEA. Kinshasa: UNIKIN, Faculté de Médecine, École de Santé Publique.

8. Salama MS, Verhoef W (2014) Stream remote sensing model for water quality mapping: 2SeaColor. Remote Sensing of the Environment (August 2014) 157: 6558-6563.

9. Ruhakana A (2011) Water quality variability and its impact on rice irrigation in Rusurirwamujyinga sub-catchment, Rwanda. Master of Science Thesis (Integrated Watershed Management, Water Chemistry). Nairobi: Kenyatta University, School of Pure and Applied Sciences, Department of Geography.

10. Doughari JH, Pukuma MS, De N (2007) Antibacterial effects of Balanitesaegyptiaca L. Drel.andMoringaOleifera Lamon Salmonella typhi. African Journal of Biotechnology 6 (19): 2212-2215.

11. Borzouei A, Kafi M, Khazaei H, Naseriyam B, Majdabadi A (2010). Effects of gamma radiation on physiological aspects of wheat (Triticumaestivum.L) Seedlings. Pak J Bot 42 (4): 2281-2290.

12. (2012) UNWATER. World water day: Coping with water disasters

13. (2014) INEC. Report of Topographic Surveys of Electoral Sites, Kenge Kinshasa: Independent National Electoral Commission (CENI).

14. (2017) City of Kenge Administrative Census 2017. Kenge: Town Hall of Kenge City, Kwango Province, DRC.

15. Pareck J, Chanda SV (2007) In vitro antimicrobial activity and phytochemical analysis of some Indian medicinal plants. Turkish Journal of Biology 31: 53-58.

16. Martin G, Caitlin Ravichandran (2006) Statistical primer for cardiovascular research: descriptive statistics and graphical displays. Circulation 115: 2005-2010.

17. Musibono DE (1999) Variations saisonnières de la teneur en Chrome hexavalent ( $\mathrm{Cr}$ 6), Cuivre ( $\mathrm{Cu}$ ), Plomb (Pb) Zinc ( $\mathrm{Zn}$ ) dissous dans quatre rivières urbaines de Kinshasa (RDC) et analyses d'impacts écologiques. Actes du 1 er colloque sur la problématique des déchets à Kinshasa, p. 81-86.

18. Malik AK, Hamdi MS (2008) Contribution à l'étude des paramètres physico-chimiques et bactériologiques de l'embouchure de l'Oued " Béni-Messous ». Mémoire de Diplôme d’Études Universitaires Appliquées (DEUA). Niamey: Université de Niger.

19. Folkard GK (1997) Development of the Moringaoleifera and M. stenopetalatree to provide valuable products: coagulant for water/ wastewater treatment and vegetable oil. Technical report for period 1/1-31.

20. Koffi N, Beugre K, Guede N, Zirihi N, Dossahoua T, et al. (2009) Screening phytochimique de quelques plantes médicinales ivoiriennes utilisées en pays krobou (Agboville, Côte-d'Ivoire), Université de Cocody-abidjan. Sciences and Nature 6 (1): 1-15.

21. Chantrel E, Saint Sauveur A (2008) Moringa oleifera in Niger and India. The Flamboyant 43: 6-23.

22. Foild N, Makkar HPS, Becker K (2002) Potential of M. oléifera for agricultural and industrial needs. In: A de Saint Sauveur, J Appora M, Besse and L Fuglie (Eds.), Development Potential for Moringa Products, Proceedings of the Dar es Salaam International Workshop, 29 October-2 November 2001 Montpellier: CIRAD / PROPAGE / SILVA.

23. Fuglie L (2002) L'arbre de la vie. Dakar: CWS/CTA.

24. Anwar F Latif S, Ashraf M, Gilani AH (2006) The case of M oleifera Phytother Res 21: 17-25.
25. Musibono DE, Mouzon J, Biey M, Puema K, Mondo M, et al. (2002) Notes on Moringaoleifera Lam Cultivation in DR. Congo and preliminary coagulation/ floculation tests. Annales de la Faculté des Sciences 1 (2): 63-66

26. Ericsson HM, Sherries JC (1971) Antibiotic sensitivity testing. Report of an International collaborative study. Act Apathol Microbial-Scand Sect B 217(Supply): 1

27. World Bank (2007) Improve access to drinking water in Mali.

28. Kambu K (1990) Éléments de phytothérapie comparée, plantes médicinales africaines. Kinshasa: Centre de Recherches Pédagogiques (CRP) 1-106.

29. Aminot A, Kerouel R (2004) Hydrologie des écosystèmes marins: Paramètres et analyses. Montpelier: Editions Ifremer pp. 336.

30. Beyene A, Luwesi CN (2018) Water Financial Innovations in Africa A Guide for Water Managers - VOL. 1: The Context of Water Financial Innovations. Uppsala: NordiskaAfrikainstitutet, pp. 159.

31. (2018) Google earth maps. Disponible sur.

32. Kapende JK, Luwesi CN (2018) Analyse multivariée discriminante de la malnutrition chronique au cours de la petite enfance dans la Province du Kwango (2013-2014). Health-Environment Sustainability Journal 7(1): 160-177.

33. Kerle N, Jansen LLF, Huumeman GC (2004) Analyse multivariée discriminante de la malnutrition chronique au cours de la petite enfance dans la Province du Kwango (2013-2014).

34. Leclerc H, Gaillard JL, et Simonet M (1994) Microbiologie générale: la bactérie et le monde bactérien. Paris: Éditions Doin pp. 356.

35. Luwesi CN, Obando JA, et Shisanya CA (2017) L'impact du réchauffement microclimatique sur les fermiers de Muooni, au Kenya. Agriculture 7(3): $1-20$.

36. OMS (1986) Directives de qualité pour l'eau de boisson, contrôle de la qualité de l'eau de boisson destinée à l'approvisionnement des petites collectivités. Organisation mondiale de la Santé 3: 341.

37. OMS (1994) Directives de la qualité sur l'eau de boisson, 2ème édition: Volulme 1 Recommandations. Organisation mondiale de la Santé.

38. OMS (2003) Manual for the laboratory identification and antimicrobial susceptibility testing of bacterial pathogens of public health importance in the developing world. Genève: Secrétariat de l'OMS pp. 103-162.

39. OMS (2004) Directives de qualité pour l'eau de boisson Vol. 1, 3ème éd. Genève: Secrétariat de l'OMS.

40. OMS (2006) Formation en management de Soins de Santé Primaire mondial sur l'hygiène, eau et assainissement. Kinshasa: Bureau de l'OMS-RDC.

41. Conseil Exécutif (2010) Stratégies pour la gestion sans risques de l'eau de boisson destinée à la consommation humaine, cent vingt-septième session: point 5,4 de l'ordre du jour provisoire du 22 avril 2010. Genève: Secrétariat de l'OMS.

42. PNUE OMS (2011) Problématique de l'eau en RDC - Défis et opportunités - Étude technique réalisée dans le cadre du programme d'évaluation environnementale post-conflit en RDC. Nairobi: Secrétariat du PNUE.

43. Shisanya CA, Luwesi CN, Obando JA (2014) Innovative but Not Feasible: Green Water Saving Schemes at the Crossroad in Semi-Arid Lands. In: P Chanie (Eds.), Innovative Water Resource Use and Management for Poverty Reduction in Sub-Saharan Africa: An Anthology. Addis Ababa: OSSREA, pp. 137-172.

44.Zhou Q (2013) Cartography and Remote Sensing Systems. Hong Kong: Hong Kong Baptist University (HKBU). 


\section{ISSN: 2574-1241}

DOI: 10.26717/BJSTR.2019.18.003101

Cush Ngonzo Luwesi. Biomed J Sci \& Tech Res

(C) (P) This work is licensed under Creative

Submission Link: https://biomedres.us/submit-manuscript.php

$\begin{array}{ll}\text { BIOMEDICAL } & \text { Assets of Publishing with us } \\ \text { RESEARCHES } & \text { - Global archiving of articles } \\ & \text { - Immediate, unrestricted online access } \\ & \text { - Rigorous Peer Review Process } \\ \end{array}$

